\title{
Eosinophilic Granuloma of the Skull Presenting as Non-Traumatic Extradural Haematoma in Children
}

This article was published in the following Dove Press journal: International Journal of General Medicine

\author{
Alaa Al-mousa iD ${ }^{1,2}$ \\ Mohammed Altarawneh ${ }^{2}$ \\ Omar Alqatawneh (iD) ${ }^{2}$ \\ Zalina Bashir ${ }^{3}$ \\ Salem Al-Dwairy ${ }^{1,2}$ \\ Anan Shtaya (iD) 4,5 \\ 'Department of General and Special \\ Surgery, Faculty of Medicine, The \\ Hashemite University, Zarqa 13133, \\ Jordan; ${ }^{2}$ Department of Surgery, Prince \\ Hamza Hospital, Amman I 1732, Jordan; \\ ${ }^{3}$ Department of Pathology, Prince Hamza \\ Hospital, Amman II732, Jordan; \\ ${ }^{4}$ Neurosciences Research Centre, \\ Molecular and Clinical Sciences Research \\ Institute, St George's University of \\ London, London, UK; ${ }^{5}$ Atkinson Morley \\ Neurosurgery Centre, St George's \\ University Hospital NHS Trust, \\ London, UK
}

\begin{abstract}
Cranial extradural haematoma (EDH) is a neurosurgical emergency that can be caused by traumatic or non-traumatic causes with the former being more prevalent. Nontraumatic causes are variable and can include infection, vascular malformation and haematological disorders. This paper will address an extremely rare non-traumatic cause of EDH. More specifically, eosinophilic granuloma (EG), the localized form of Langerhans histiocytosis, may involve the skull and has rarely been reported to present with EDH. The case that will be presented is that of a three-year-old male patient, who presented with progressive vomiting and drowsiness, associated with left parietal swelling. CT scan of the brain showed an extradural haematoma and an osteolytic parietal lesion. He underwent emergent craniectomy, evacuation of the haematoma and dura resection as the lesion was infiltrating the dura. Histopathological examination of the dura and the bone edges showed eosinophilic granuloma (EG). The mechanism of a haemorrhage in this situation is poorly understood and the literature is extremely scarce. In conducting a thorough literature review, only 11 case reports of EG causing non-traumatic EDH were found. The details of these 11 cases will be reviewed and discussed in this paper, in addition to our illustrative case.
\end{abstract}

Keywords: extradural haematoma, eosinophilic granuloma, Langerhans cell histiocytosis, spontaneous, non-traumatic, cranial, skull

\section{Introduction}

The first case of a non-traumatic extradural haematomas (NTEDH) due to infection has been reported by Schneider et al in 1951. ${ }^{1}$ Since then, a wide array of pathologies have been described. This includes infection, neoplastic, vascular and coagulopathies. ${ }^{2}$ The entity of NTEDH remains uncommon and cases with no underlying pathology, despite adequate investigation, are rare. ${ }^{2}$

Eosinophilic granuloma (EG) has been described as an unusual cause of NTEDH. EG is an uncommon subtype of Langerhans cell histiocytosis (LCH) that mainly affects children and presents, by and large, as a destructive bony lesion. $^{3}$ The most common site of involvement is the skull. ${ }^{3}$ A spontaneous NTEDH due to a solitary EG is extremely rare. Patients may present with painless mass and/or symptoms of raised intracranial pressure. EG can be managed conservatively. However, this may be different when associated with EDH. Therefore, a review of the literature can provide an up to date summary of the presentation and management of this rare pathology. 
In this regard, we reviewed the literature for EG causing extradural haematoma. Furthermore, we describe our illustrative case. This is the twelfth case in the literature, in which both bone and dura were infiltrated with the disease.

\section{Materials and Methods}

We present the case of a 3-year-old boy with eosinophilic granuloma, presenting with non-traumatic EDH and a review of the English literature for reports of eosinophilic granuloma presenting with non-traumatic extradural haematoma (NTEDH). A literature search was performed using the PubMed search engine. Combinations of the following terms were used: "Spontaneous extradural hematoma" OR "Spontaneous epidural hematoma" OR "nontraumatic extradural hematoma" OR "nontraumatic epidural hematoma" OR "non-traumatic epidural hematoma" OR "nontraumatic extradural hematoma". The search was limited to a Human and English language literature. The first and second authors reviewed all the search results independently. All articles reporting eosinophilic granuloma presenting or associated with EDH were included. Figure 1 clarifies the review process. We identified 11 papers published between 1977 and 2016 that fulfilled the inclusion criteria of our literature review. All cases of NTEDH secondary to EG were extracted, tabulated and discussed.

\section{Illustrative Case History and Examination}

A three-year-old boy with no past medical history presented to the accident and emergency department with recurrent, progressive vomiting and drowsiness over two days. This was associated with left parietal swelling, which was noticed by his mother, coincided with the onset of symptoms. There was no history of trauma and family history was unremarkable. The patient was neurologically intact. There was a firm, non-tender, rounded, non-fluctuant or pulsating mass measuring $3 \times 3 \mathrm{~cm}$ in diameter in his left parietal region. All blood tests, including platelet count and coagulation profile, were normal.

A head CT scan revealed a $3 \times 3.5 \mathrm{~cm}$ osteolytic lesion, bevelled bony edges and a punched-out appearance just posterior to the left coronal suture edge, with intracranial sequestrum and soft tissue swelling extending into the subcutaneous plane. An extradural mixed density lesion $(1.5 \times 5.4 \times 5 \mathrm{~cm})$ with two different Hounsfield scales (blood and soft tissue). Contrast-enhanced CT showed some irregular enhancement (Figure 2).

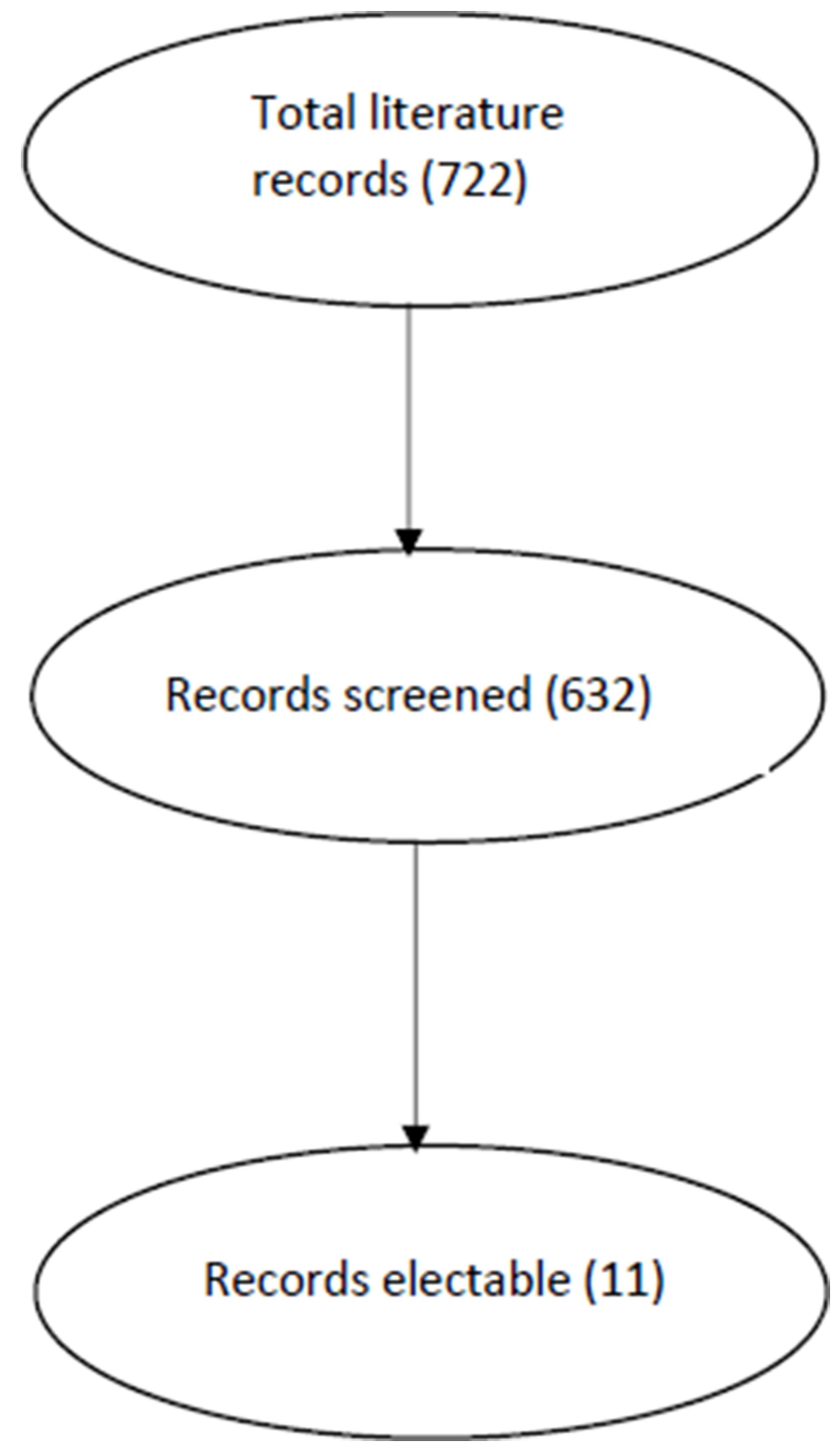

Figure I Flowchart of literature review process: exclusion of non-English, nonhuman literature; exclusion of non-cranial, non extradural, non esionophillic granuloma cases.

\section{Surgery and Postoperative Course}

The patient underwent emergent craniotomy for surgical removal of the mass lesion and evacuation of the EDH. A grey to purple, non-adherent mass, was encountered when the scalp flap was reflected with $2 \times 2.5$ bony defect. A wide craniotomy with its edges $2 \mathrm{~cm}$ off the lesion was raised. There was a soft tissue mass lesion adherent and infiltrating the underlying dura and surrounded by clotted blood with no specific source of bleeding. Multiple samples were sent for frozen section, which showed inflammatory cells; however, malignancy could not be ruled out. The infiltrated dura was resected along with the lesion followed by duroplasty utilizing the pericranium. Given the nonconclusive frozen section results and the dural involvement, 


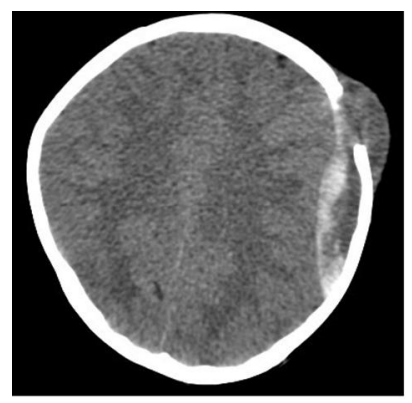

A

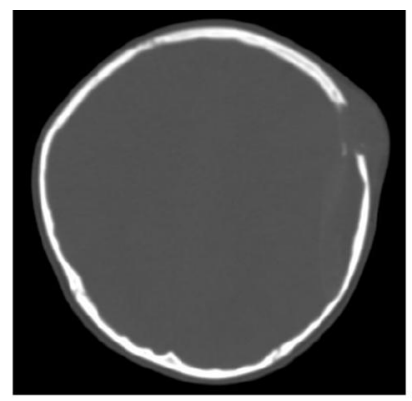

B

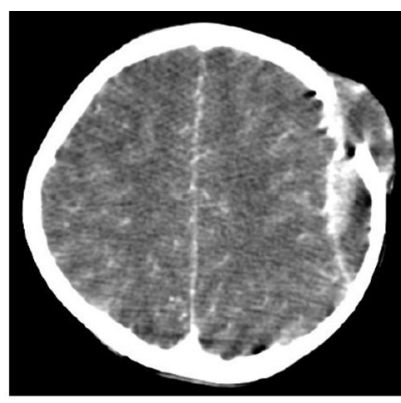

C

Figure 2 (A) Axial non-contrast CT brain reveals iso-dense subcutaneous scalp lesion, underlying osteolytic bony defect and mixed density extradural lesion. (B) Axial CT head (bone window) shows bevelled bony edges and punched out appearance just posterior to the left coronal suture edge, with an intracranial sequestrum. (C) PostContrast axial CT scan images showing irregular dural and mass lesion enhancement.

the bone flap was sent for histopathological examination and the craniotomy converted to a craniectomy. The postoperative course was uneventful, and the patient was discharged home on the 4th day, post operation. Further work up, including skeletal survey, isotope bone scan, chest X-ray, MRI brain (Figure 3) and bone marrow aspiration were performed and revealed no other lesions nor systemic involvement. At his three months follow up, the child was well and an uneventful cranioplasty was performed.

\section{Pathological Findings}

The histopathology revealed a cystically degenerated tumor composed of a sheath of large oval cells with an ample cytoplasm and a fine chromatin with longitudinal grooves mixed with numerous eosinophils, plasma cells, giant cells, foamy macrophages and small lymphocytes. These cells were positive for CD1a, S-100 and paranuclear CD68. The histopathological findings were suggestive of an eosinophilic granuloma (Figure 4).

\section{Literature Review Results}

Including the current report, a total of 12 cases of eosinophilic granuloma with $\mathrm{EDH}$ are reported in the literature (Table 1$)^{3-13}$. Eleven were males (92\%), with an age range from 2 to 15 years (mean age 6.9 years, median 7.5 years). The occipital bone was involved in half of the 12 reported cases $(50 \%)$, four parietal $(33 \%)$, one frontal $(8 \%)$ and one temporal $(8 \%)$. While the parietal bone is the most common site for skull vault involvement without EDH as reported by Colas et al. ${ }^{14}$ Ten of the patients in this review

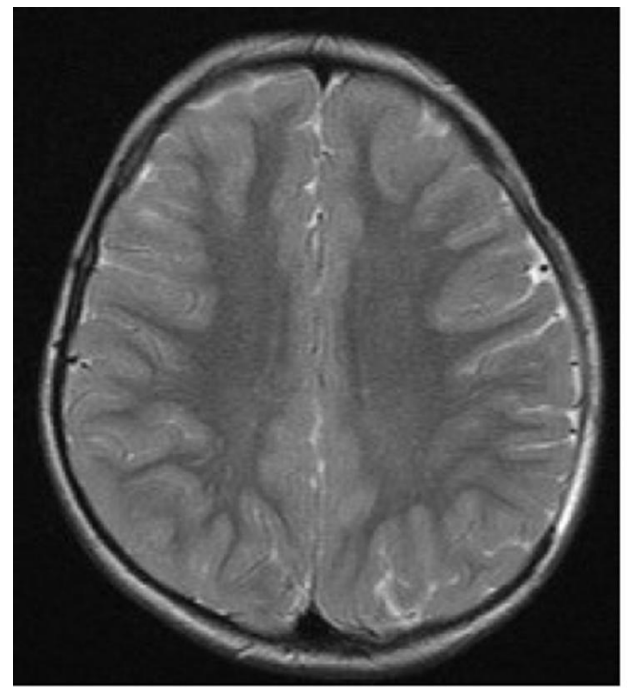

A

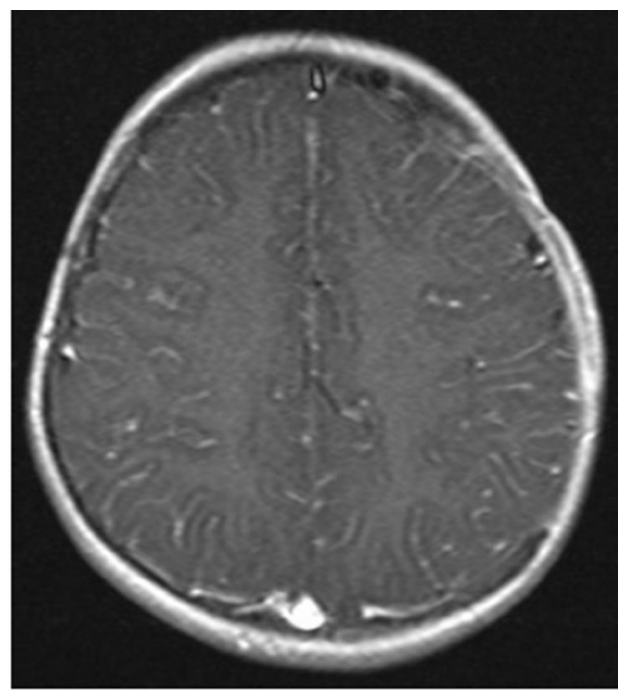

B

Figure 3 (A and B) Post-operative MRI (A- T2W axial MR and B-TIW post contrast image) both showing resolution of the extradural haematoma and no evidence of any other lesions. 


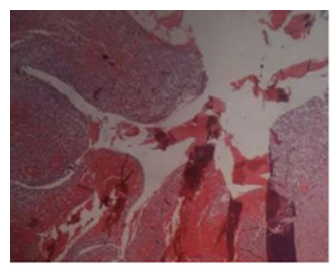

A

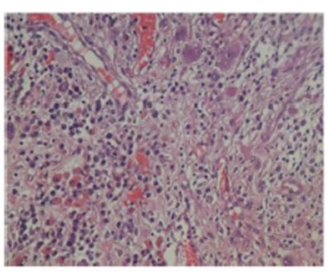

B

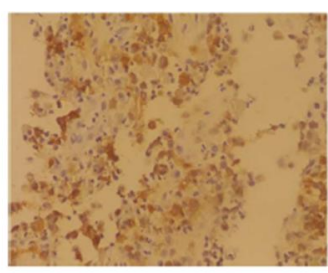

C

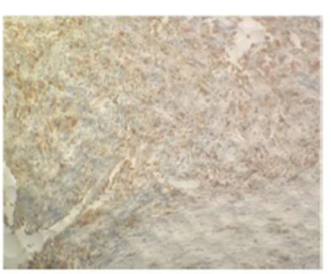

D

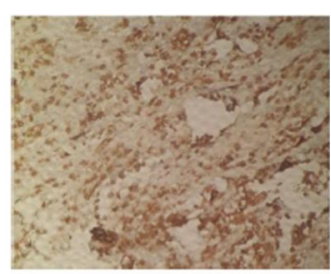

E

Figure 4 (A) Photomicrograph showing a secondary cystic degeneration surrounded by remnant tumour with an extensive haemorrhage. (B) Sheets of large oval cells with abundant pale to eosinophilic cytoplasm, linear grooves and inconspicuous nucleoli. Infiltrates of Langerhans cells, macrophages, lymphocytes, plasma cells and variable eosinophils are seen. (C-E) The tumour cells are positive for Cdla, SI00 and CD68.

presented acutely with symptoms of increased intracranial pressure (headache and vomiting) and two with growing scalp lesions. All had history of a scalp lesion, duration ranged between 2 days and 18 months. Half of them were tender, four non-tender and two case reports did not clarify the lesion tenderness. Five of the patients had history of minor trauma ( 3 days -1 month) prior to the presentation. All patients underwent craniotomy and haematoma evacuation, with no reported adverse outcomes from surgery. We note that EG symptoms were progressive over days or even months compared to our case, which presented with the shortest symptomatic period of 2 days.

\section{Discussion}

$\mathrm{EDH}$, which is associated with a skull fracture in $65 \%$ to $90 \%$ of cases $^{15}$ is most commonly the result of head

Table I Summary of All Reported Cases of Eosinophilic Granuloma Associated with Extradural Hematoma

\begin{tabular}{|c|c|c|c|c|c|c|c|}
\hline \multirow[t]{2}{*}{ Author/Year } & \multirow[t]{2}{*}{ Gender } & \multirow{2}{*}{$\begin{array}{l}\text { Agel } \\
\text { Yrs }\end{array}$} & \multicolumn{4}{|c|}{ Presentation } & \multirow[t]{2}{*}{ Site of Lesion } \\
\hline & & & Mass & Duration & Trauma & Symptoms & \\
\hline $\begin{array}{l}\text { Manaka et al./ } \\
1977^{4}\end{array}$ & Female & 4 & $\begin{array}{l}\text { Non- } \\
\text { tender }\end{array}$ & I months & $\begin{array}{l}\text { Yes/3 } \\
\text { days }\end{array}$ & Headache, nausea, and vomiting & $\begin{array}{l}\text { Midline } \\
\text { Occipital }\end{array}$ \\
\hline Lee et al. $/ 2000^{5}$ & Male & 8 & Tender & 2 weeks & $\begin{array}{l}\text { Yes } / 4 \\
\text { weeks }\end{array}$ & $\begin{array}{l}\text { Headache, emesis, paraesthesia's of the left arm, } \\
\text { and photophobia }\end{array}$ & $\begin{array}{l}\text { Midline } \\
\text { Occipital }\end{array}$ \\
\hline Cho et al./2001 ${ }^{13}$ & Male & 2 & Present & $\begin{array}{l}18 \\
\text { months }\end{array}$ & No & Unconsciousness & Occipital \\
\hline Chen et al. $/ 2002^{3}$ & Male & 2 & Tender & 3 months & No & Sudden onset of drowsy consciousness & Occipital \\
\hline $\begin{array}{l}\text { Martinez-Lage } \\
\text { et al. } / 2002^{6}\end{array}$ & Male & 9 & Tender & 2 weeks & $\begin{array}{l}\text { Yes } / 2 \\
\text { weeks }\end{array}$ & Headaches, drowsiness and vomiting & Occipital \\
\hline Mut et al. $/ 2004^{7}$ & Male & 9 & Tender & 3 months & No & Progressive headache, nausea and vomiting & Occipital \\
\hline Lee et al. $/ 2008^{8}$ & Male & 10 & $\begin{array}{l}\text { Non- } \\
\text { tender }\end{array}$ & I months & $\begin{array}{l}\text { Yes/l } \\
\text { month }\end{array}$ & None & Midline Frontal \\
\hline Bhat et al. $/ 2010^{9}$ & Male & 10 & Tender & I months & No & None & Parietal \\
\hline $\begin{array}{l}\text { Pawar et al./ } \\
2011^{10}\end{array}$ & Male & 4 & Present & I month & $\begin{array}{l}\text { Yes/l } \\
\text { month }\end{array}$ & Unremitting headache, projectile vomiting & Parietal \\
\hline $\begin{array}{l}\text { Bakhaidar et al./ } \\
2016^{12}\end{array}$ & Male & 7 & $\begin{array}{l}\text { Non- } \\
\text { tender }\end{array}$ & 2 months & No & $\begin{array}{l}\text { Progressive headache, vomiting, and decreased } \\
\text { level of consciousness }\end{array}$ & Parietal \\
\hline $\begin{array}{l}\text { Sadashiva et al./ } \\
2016^{11}\end{array}$ & Male & 15 & Tender & 3 months & No & A diffuse intractable headache & Temporal \\
\hline $\begin{array}{l}\text { Current case/ } \\
2020\end{array}$ & Male & 3 & $\begin{array}{l}\text { Non- } \\
\text { tender }\end{array}$ & 2 days & No & $\begin{array}{l}\text { Recurrent and progressive vomiting and } \\
\text { drowsiness }\end{array}$ & $\begin{array}{l}\text { Parietal/coronal } \\
\text { sutures }\end{array}$ \\
\hline
\end{tabular}


injuries in young and middle-aged people. Iatrogenic injuries may result in a spontaneous EDH such as postcranial surgery with an incidence rate of $1 \%{ }^{16}$ and distant site surgery that includes spine surgery and open heart surgery. ${ }^{2,17}$ Non-traumatic extradural haematoma is a rare disease that is caused by a heterogeneous group of pathological disorders. Infections such as otitis media, paranasal sinusitis and orbital infections have been implicated as causes of NTEDH. ${ }^{12}$ Bleeding disorders, vascular malformations and neoplastic condition are among the other reported causes of NTEDH. Hettige et $\mathrm{al}^{18}$ reviewed 22 cases of sickle cell anaemia associated with EDH of which several were associated with a skull bone infarction. NTEDH is also associated with chronic kidney disease ${ }^{19}$ and systemic lupus erythematosus ${ }^{2}$. Other pathologies such as plasmacytoma, Ewing's sarcoma and subdural haematoma may be disguised as $\mathrm{EDH}^{20,21}$

Lichtenstein and Jaffe first introduced eosinophilic granuloma (EG) in $1940 .^{22} \mathrm{EG}$ is characterised by single or multiple skeletal lesions and is the most common form of Langerhans histiocytosis (LCH). Two-thirds of EG's are unifocal with bone involved in about $70-80 \%$ of cases with the axial skeleton being the predominant site of involvement. ${ }^{23}$ Almost all body systems have been reported to be affected by LCH lesions. ${ }^{24}$ The outcome spectrum ranges from a self-remitting disease to a rapidly progressive one that might be fatal. ${ }^{25}$ Lieberman et al reviewed a total of 238 patients with $\mathrm{LCH} ; 64.3 \%$ of them had unifocal involvement, with patient ages ranging from 1 month to 66 years (mean age, 17.6 years; median, 11 years). Two-thirds of the patients were males $(65.1 \%)$. They also reported the skull to be the most frequent site of involvement in $16 \%$ of unifocal cases. $^{23}$ However, the previous two series did not discuss $\mathrm{LCH}$ or EG as a cause of EDH. There is a lack of agreement on the optimal management of EG; observation, surgical (resection or curettage), steroid injection, and NSAID's therapy, all have been proposed as possible management options. Several case series were reported complete or had partial healing in almost all patients with EG treated with observation. Local corticosteroids injections can result in complete healing in $75 \%$ of cases. ${ }^{26}$ The published guidelines of "The Euro Histio Net project" in 2013 did not recommend resection for lesions $>5 \mathrm{~cm}$ due to the risks of bone defect, prolonged healing and skeletal deformity. On the other hand, smaller lesions $<2 \mathrm{~cm}$ would be appropriate for surgical resection. ${ }^{25}$ The surgical decision should be based on clinical presentation, size, location, systemic involvement, and the certainty of the diagnosis. In functionally critical anatomical areas such as the skull, orbit, and vertebral column with the risk of disease progression and compression on adjacent structures, surgical resection is justified. All reported patients having EG associated NTEDH underwent surgical resection and haematoma evacuation due to the presence of EDH or its presenting symptoms.

The aggressive surgical management of our patient was judged by the urgency of the presentation, the unusual dural infiltration, and inconclusive frozen section results. Although this has resulted in perhaps an unnecessary craniectomy and a second surgery for cranioplasty, this was a reasonable decision in an emergency. None of the other cases reported dural infiltration as such, their management was limited to evacuation of the haematoma. High index of suspicion, good communication with pathologist and further work up when appropriate are essential to improve the outcome.

The mechanism of EDH formation in skull EG is not clearly understood. Anecdotal trauma has been reported in $33-50 \%$ of symptomatic EG cases. ${ }^{7}$ Associated trauma cannot alone explain the formation of EDH; history of preceding minor trauma reported in only five out of the twelve cases in our literature review. Intra-tumoral haemorrhage with extension into the epidural space was proposed by Sadashiva et $\mathrm{al}^{11}$ as a possible underlying mechanism for formation of EDH. Also, it was proposed that NTEDH can result from stripping of dura due to growth, intra-diploic and dural surface vessel erosion, and bleeding from a localized neovascularization of the dura. ${ }^{12}$ Proliferation of endothelial cells within tumour vasculature leading to an occlusion or necrosis, tumour vessel fragility, and infiltration of tumour cells into the vessel walls are a proposed mechanism for intra-tumoral haemorrhage. ${ }^{27}$ All patients with NTEDH due to EG had no other lesions or systemic disease and recovered fully.

The management of NTEDH is determined by several factors: the clinical presentation, radiological features of the EDH, and the ability to identify the underlying pathology prior to surgery. The first two factors will determine the urgency of treatment while the third will determine the most appropriate intervention.

In conclusion, trauma remains by far the most common cause of EDH (other aetiologies are rare). Detailed knowledge of non-traumatic causes is crucial for optimal management of patients, especially when there is no history of trauma.

\section{Ethics Approval}

This study was approved by the Institutional Review Board at The Hashemite University. The approval number $520 / 09 / 2020$. 


\section{Consent for Publication}

The Manuscript does not contain any patient identifiable data. Patient parent signed an informed consent for publication.

\section{Funding}

This study was completed with no dedicated funding.

\section{Disclosure}

The authors report no conflicts of interest for this work.

\section{References}

1. Schneider RC, Hegarty WM. Extradural hemorrhage as a complication of otological and rhinological infections. Ann Otol Rhinol Laryngol. 1951;60(1):197-206. doi:10.1177/000348945106000116

2. Ng WH, Yeo TT, Seow WT. Non-traumatic spontaneous acute epidural haematoma - report of two cases and review of the literature. J Clin Neurosci. 2004;11(7):791-793. doi:10.1016/j.jocn.2003.12.002

3. Chen HC, Shen WC, Chou DY, Chiang IP. Langerhans cell histiocytosis of the skull complicated with an epidural hematoma. Am J Neuroradiol. 2002;23:493-495.

4. Manaka S, Izawa M, Nawata H. Skull tumor simulating sinus pericranii. Case report. J Neurosurg. 1977;46(5):671-673. doi:10.3171/ jns.1977.46.5.0671

5. Lee KW, McLeary MS, Zuppan CW, Won DJ. Langerhans' cell histiocytosis presenting with an intracranial epidural hematoma. Pediatr Radiol. 2000;30(5):326-328. doi:10.1007/s002470050750

6. Martinez-Lage JF, Bermudez M, Martinez-Barba E, Fuster JL, Poza M. Epidural hematoma from a cranial eosinophilic granuloma. Childs Nerv Syst. 2002;18(1-2):74-76. doi:10.1007/s003810100491

7. Mut M, Cataltepe O, Bakar B, Cila A, Akalan N. Eosinophilic granuloma of the skull associated with epidural haematoma: a case report and review of the literature. Childs Nerv Syst. 2004;20 (10):765-769. doi:10.1007/s00381-004-0913-7

8. Lee YS, Kwon JT, Park YS. Eosinophilic granuloma presenting as an epidural hematoma and cyst. J Korean Neurosurg Soc. 2008;43 (6):304-306. doi:10.3340/jkns.2008.43.6.304

9. Bhat AR, Jain AK, Kirmani AR, Nizami F. Pathological intracranial extradural hematoma in a 10-year-old child. $J$ Pediatr Neurosci. 2010;5(2):164-166. doi:10.4103/1817-1745.76121

10. Pawar RV, Hagiwara M, Milla S, Wisoff J, George AE. Eosinophilic granuloma presenting as post-traumatic scalp hematoma with epidural hemorrhage. A case report. Neuroradiol J. 2011;24 (5):767-771. doi:10.1177/197140091102400516

11. Sadashiva N, Baruah S, Rao S, et al. Eosinophilic granuloma of skull with fluid level and epidural hematoma: a case report and review of the literature. Pediatr Neurosurg. 2017;52(1):41-45. doi:10.1159/ 000448047
12. Bakhaidar MG, Alghamdi FA, Baeesa SS. Spontaneous extradural hemorrhage due to Langerhans cell histiocytosis of the skull in a child: a rare presentation. $J$ Pediatr Neurosci. 2016;11(1):52-55. doi:10.4103/1817-1745.181248

13. Cho DY, Liau WR, Chiang IP. Eosinophilic granuloma with acute epidural hematoma: a case report. Pediatr Neurosurg. 2001;35 (5):266-269. doi:10.1159/000050434

14. Colas L, Caron S, Cotten A. Skull vault lesions: a review. AJR Am J Roentgenol. 2015;205(4):840-847. doi:10.2214/AJR.14.13415

15. Bolliger SA, Thali MJ, Zollinger U. Nontraumatic intracranial epidural hematoma: a case report. Am J Forensic Med Pathol. 2007;28 (3):227-229. doi:10.1097/PAF.0b013e3181405f14

16. Fukamachi A, Koizumi H, Nagaseki Y, Nukui H. Postoperative extradural hematomas: computed tomographic survey of 1105 intracranial operations. Neurosurgery. 1986;19(4):589-593. doi:10.1227/ 00006123-198610000-00013

17. Li ZJ, Sun P, Dou YH, et al. Bilateral supratentorial epidural hematomas: a rare complication in adolescent spine surgery. Neurol Med Chir (Tokyo). 2012;52(9):646-648. doi:10.2176/nmc.52.646

18. Hettige S, Sofela A, Bassi S, Chandler C. A review of spontaneous intracranial extradural hematoma in sickle-cell disease. Acta Neurochir (Wien). 2015;157(11):2025-2029. doi:10.1007/s00701015-2582-6

19. Yadav P, Verma A, Chatterjee A, Srivastava D, Riaz MR, Kannaujia A. Spontaneous extradural hemorrhage in a patient with chronic kidney disease: a case report and review of literature. World Neurosurg. 2016;90:707.e13-707.e16. doi:10.1016/j.wneu.2016.03.036

20. Rutherford SA, Leach PA, Richardson PL. Solitary skull vault plasmacytoma masquerading as an extradural haematoma. Acta Neurochir (Wien). 2004;146(8):863-864. doi:10.1007/s00701-0040297-1

21. Prasad GL, Menon GR. Lentiform subdural hematoma - a rare mimicker of extradural hematoma. World Neurosurg. 2017;97:738-741. doi:10.1016/j.wneu.2016.08.109

22. Lichtenstein L, Jeffe HL. Eosinophilic granuloma of bone: with report of a case. Am J Pathol. 1940;16(5):595-604.3.

23. Lieberman PH, Jones CR, Filippa DA. Langerhans cell (eosinophilic) granulomatosis. J Invest Dermatol. 1980;75(1):71-72. doi:10.1111/ 1523-1747.ep12521252

24. Collin M, Bigley V, McClain KL, Allen CE. Cell(s) of origin of langerhans cell histiocytosis. Hematol Oncol Clin North Am. 2015;29 (5):825-838. doi:10.1016/j.hoc.2015.06.003

25. Haupt R, Minkov M, Astigarraga I, et al. Langerhans cell histiocytosis (LCH): guidelines for diagnosis, clinical work-up, and treatment for patients till the age of 18 years. Pediatr Blood Cancer. 2013;60 (2):175-184. doi:10.1002/pbc.24367

26. DiCaprio MR, Roberts TT. Diagnosis and management of langerhans cell histiocytosis. J Am Acad Orthop Surg. 2014;22(10):643-652. doi:10.5435/JAAOS-22-10-643

27. Uranishi R, Nikaido Y, Eguchi T, Bessho H, Fujimoto T, Inui T. Eosinophilic granuloma associated with intratumoral hemorrhage case report. Neurol Med Chir (Tokyo). 1996;36(7):458-461. doi:10.2176/nmc.36.458
International Journal of General Medicine

\section{Publish your work in this journal}

The International Journal of General Medicine is an international, peer-reviewed open-access journal that focuses on general and internal medicine, pathogenesis, epidemiology, diagnosis, monitoring and treatment protocols. The journal is characterized by the rapid reporting of reviews, original research and clinical studies across all disease areas. The manuscript management system is completely online and includes a very quick and fair peer-review system, which is all easy to use. Visit http://www.dovepress.com/ testimonials.php to read real quotes from published authors. 